\title{
PENINGKATAN AKTIVITAS BELAJAR BIOLOGI SISWA MENGGUNAKAN MODEL PEMBELAJARAN KOOPERATIF TIPE JIGSAW DI KELAS XII MIPA 3 SMA N 1 PULAU PUNJUNG TAHUN PELAJARAN 2019/2020
}

\author{
Agustin MN \\ Guru SMA Negeri 1 Pulau Punjung \\ agustinmn165@gmail.com
}

\begin{abstract}
The purpose of this study was to determine whether student learning activities in economic learning could be improved by applying the Jigsaw Model of Cooperative Learning Method. This study involved students of class X IIS 2 at SMA N 1 Pulau Punjung in Academic Year 2019/2020 and one economics teacher as an observer. This study consisted of two cycles, each cycle consisting of three meetings by applying the Jigsaw Model of Cooperative Learning Method. The results in the first cycle have not shown significant activity, so the second cycle continued. The comparison students acitivities has increased 23,79\% from 33,71 \% to 57,50\%. Based on the results of this study, researcher suggests other economics teachers to use appropriate learning methods such as this Jigsaw Method, learning becomes more fun and obtains satisfying results.
\end{abstract}

Keywords: Learning Activities, Biology Subjects, Jigsaw

\begin{abstract}
Abstrak
Tujuan penelitian ini adalah untuk mengetahui apakah aktivitas belajar siswa dalam pembelajaran ekonomi dapat ditingkatkan dengan menerapkan Model Pembelajaran Kooperatif Model Jigsaw. Penelitian ini melibatkan siswa kelas X IIS 2 SMA N 1 Pulau Punjung Tahun Pelajaran 2019/2020 dan satu orang guru ekonomi sebagai pengamat. Penelitian ini terdiri dari dua siklus, setiap siklus terdiri dari tiga pertemuan dengan menerapkan Metode Pembelajaran Kooperatif Model Jigsaw. Hasil pada siklus I belum menunjukkan aktivitas yang signifikan, sehingga siklus II dilanjutkan. Perbandingan aktivitas siswa mengalami peningkatan $23,79 \%$ dari $33,71 \%$ menjadi $57,50 \%$. Berdasarkan hasil penelitian ini peneliti menyarankan kepada guru ekonomi lainnya untuk menggunakan metode pembelajaran yang tepat seperti Metode Jigsaw ini, pembelajaran menjadi lebih menyenangkan dan memperoleh hasil yang memuaskan.
\end{abstract}

Kata kunci: Aktivitas Belajar, Mata Pelajaran Biologi, Metode Pembelajaran Kooperatif Model Jigsaw

\section{PENDAHULUAN}

Biologi adalah mata pelajaran yang mempelajari materi dan perubahan yang terjadi di dalamnya. Namun selama ini masih banyak siswa yang mengalami kesulitan dalam memahami dan mengikuti pelajaran biologi. Hal ini tidak terlepas dari materi yang dipelajari dalam biologi lebih bersifat abstrak. Adanya kesulitan atau kekurangsenangan siswa terhadap pelajaran biologi dapat disebabkan oleh 
dua faktor, yaitu faktor internal yang berasal dari dalam diri siswa dan faktor eksternal yang berasal dari luar diri siswa. Faktor internal ini dipengaruhi oleh tiga faktor yaitu faktor jasmaniah, faktor psikologis, dan faktor kelelahan. Sedangkan faktor eksternal yang mempengaruhi siswa dalam kegiatan belajar adalah faktor keluarga, faktor sekolah, dan faktor masyarakat (Slameto, 2003:54).

Kenyataan di lapangan ditemukan khususnya di SMA N 1 Pulau Punjung strategi pembelajaran yang diharapkan sesuai dengan pembelajaran sains diatas masih belum terlaksana seperti yang diharapkan, masih terlihat rendahnya motivasi siswa dalam pembelajaran, siswa masih cenderung pasif, yang berimplikasi terhadap rendahnya kwalitas hasil belajar. Hasil analisis ulangan harian pada konsep Respirasi di kelas XII MIPA 3 SMA N 1 Pulau Punjung ratarata 6,02 dengan ketuntasan klasikal 60\%. Ini masih memerlukan perbaikan dalam proses pembelajaran.

lain:

Rendahnya hasil pembelajaran disebabkan oleh beberapa faktor antara

1. kurangnya motivasi siswa dalam proses pembelajaran baik motivasi intrinsik maupun motivasi ekstrinsik.

2. Pemilihan metoda atau model pembelajaran yang sesuai dengan pendekatan sains belum terlaksana secara maksimal.

3. Kurang terampilnya guru dalam memotivasi siswa secara ektrinsik dalam pembelajaran, dalam menggunakan media, guru sebagian menggambar dipapan tulis,sehingga tidak menarik bagi siswa.

Belajar merupakan suatu proses mendapatkan pengetahuan melalui pengalaman. Adanya hasil belajar tersebut hendaknya nampak dari perubahan tingkah laku seseorang. Slameto (2003:2) menyatakan belajar adalah suatu proses usaha yang dilakukan seseorang untuk memperoleh suatu perubahan tingkah laku yang baru secara keseluruhan, sebagai hasil pengalaman sendiri dalam interaksi dengan lingkungannya

Aktivitas belajar adalah suatu tindakan yang melibatkan fisik maupun psikis pada diri seseorang untuk mencapai suatu tujuan yaitu tujuan belajar menurut Mulyono (2009:12) aktivitas siswa merupakan kegiatan atau perilaku yang terjadi selama proses belajar mengajar yaitu kegiatan yang mengarah pada proses belajar seperti bertanya, mengajukan pendapat, mengerjakan tugas, dapat menjawab pertanyaan guru dan bisa berkerja sama dengan siswa lain, serta tanggung jawab terhadap tugas yang diberikan. Belajar dikatakan berhasil mestilah melalui berbagai macam aktivitas, baik aktivitas fisik maupun psikis.

Dalam model pembelajaran Jigsaw siswa melakukan suatu kegiatan belajar dengan cara berkerja sama dengan siswa lain untuk mencapai suatu tujuan. Siswasiswa ini berkerja sama untuk menyelesaikan tugas kooperatifnya dalam: a) belajar dan menjadi ahli dalam subtopik bagiannya; b) merencanakan bagaimana mengajarkan subtopik bagiannya kepada anggota kelompoknya semula. Setelah itu, siswa tersebut kembali lagi ke kelompok masing-masing sebagai "ahli" dalam subtopiknya dan mengajarkan informasi penting dalam subtopik tersebut kepada temanya. Ahli dalam subtopik lainnya juga bertindak serupa. Sehingga seluruh siswa bertanggung jawab untuk menunjukkan penguasaannya terhadap seluruh materi yang ditugaskan oleh guru. Dengan demikian, setiap siswa dalam kelompok harus menguasai topik secara keseluruhan. 
Menurut Rusman (2010) langkah-langkah model Jigsaw sebagai berikut:

1. Siswa dikelompokkan dengan anggota \pm 4 orang

2. Tiap orang dalam tim diberi materi dan tugas yang berbeda

3. Anggota dari tim yang berbeda dengan penugasan yang sama membentuk kelompok baru (kelompok ahli).

4. Setelah kelompok ahli berdiskusi,tiap anggota kembali ke kelompok asal dan menjelaskan kepada anggota kelompok tentang subbab yang mereka kuasai.

5. Tiap tim ahli mempresentasikan hasil diskusinya

6. Guru memberi evaluasi

7. Penutup

\section{METODOLOGI PENELITIAN}

Penelitian Tindakan Kelas ini di lakukan di SMAN 1 Pulau Punjung. Kegiatan penelitian dilaksanakan mulai tanggal 1 September sampai dengan 03 Desember 2019.

Rencana tindakan yaitu gambaran tentang langkah riil yang akan dilakukan dalam tindakan. Ada 4 tahapan yang dilalui dalam penelitian tindakan ini yaitu:

1. Perencanaan

2. Pelaksanaan

3. Pengamatan

4. Refleksi

\section{HASIL PENELITIAN DAN PEMBAHASAN}

Penelitian akan dilakukan dalam dua siklus yang masing-masing siklus terdiri dari: perencanaan, pelaksanaan, observasi, dan refleksi. Pada siklus pertama terdiri dari dua kali pelaksanaan tindakan pembelajaran (dua kali pertemuan) dan siklus kedua juga dua kali pelaksanaan tindakan pembelajaran (dua kali pertemuan). Secara lebih rinci langkah-langkah penelitian pada pertemuan setiap siklus adalah sebagai berikut .

\section{Pelaksanaan Tindakan}

a. Siklus I, dilaksanakan pada kelas XII. MIPA 3 pada tanggal 27 dan 28 Oktober 2019, dengan materi sistem pertumbuhan dan perkembangan. Diakhir pembelajaran diberikan latihan soal.

b. Siklus II, dilaksanakan pada kelas XII.MIPA 3 tanggal 3 dan 4 November 2019, dengan materi sistem metabolisme. Diakhir pembelajaran diberikan latihan soal.

Dalam penelitian ini peneliti melaksanakan tindakan pembelajaran sesuai dengan skenario:

1. Kegiatan Inti.

a. Siswa diminta mencabut lot untuk menentukan materi mana yang harus dikuasainya (terdiri dari 4 sub materi)

b) Siswa yang mempunyai nomor yang sama (materi yang sama) berkumpul berdiskusi untuk menguasai materi yang ditugaskan kepada mereka, dan menyusun strategi untuk menyampaikan kepada temannya kelompok ini disebut kelompok ahli. 
c) Siswa ahli tiap topik kembali kedalam kelompok asal dan menerangkan kepada siswa pada kelompok asalnya dengan cara yang bergantian (Kelompok asal ini yang disebut kelompok Jigsaw)

d) Siswa memproleh kuis individu yang mencakup semua topik.

2. Kegiatan Akhir

a) Penghitungan skor kelompok

b) Guru memberikan reward pada kelompok yang berhasil dengan nilai yang baik dan memotivasi kelompok yang nilai masih dibawah ketuntasan minimal (KKM).

\section{Observasi}

Selama pelaksanaan pembelajaran berlangsung siswa diamati oleh seorang guru teman sejawat sebagi observer, yakni sebagai guru Biologi di SMAN 1 Pulau Punjung.

\section{Refleksi}

Guru dan kolaborator menganalisis dan merefleksi pelaksanaan hasil tindakan pembelajaran dengan menerapkan model pembelajaran kooperatif tipe Jigsaw. Untuk keperluan analisis ini dilakukan kegiatan antara lain memeriksa lembar observasi. Hasil analisis dan refleksi terhadap tidakan I ini menjadi bahan pelaksanaan tindakan berikutnya.

Kemudian dilanjutkan dengan pelaksanaan pembelajaran siklus II dengan bertitik tolak pada hasil refleksi pada siklus I. Kemudian menganalisis dan melakukan refleksi keseluruhan tindakan pembelajaran dengan menerapkan model pembelajaran kooperatif tipe Jigsaw. Kegiatan ini merupakan akhir dari tindakan I sampai tindakan II.

Deskripsi Hasil penelitian diuraikan dalam tahapan yang berupa siklussiklus pembelajaran yang dilakukan. Dalam penelitian ini pembelajaran ini dilakukan dalam dua siklus.

1. Data Aktivitas Belajar Positif Siswa

Adapun hasil perhitungan observer terhadap aktivitas belajar positif pada siklus I adalah sebagai berikut :

Tabel 1. Hasil Observasi Aktivitas Belajar positif Siswa Siklus I

\begin{tabular}{|c|c|c|c|c|c|}
\hline \multirow[t]{2}{*}{ No } & \multirow[t]{2}{*}{ Aktivitas Belajar Positif } & \multicolumn{3}{|c|}{ Jumlah Siswa } & \multirow[t]{2}{*}{$\%$} \\
\hline & & Pert.1 & Pert. 2 & Rerata & \\
\hline 1. & Aktif berdiskusi dalam kelompoknya & 14 & 15 & 14,5 & 45,2 \\
\hline 2. & $\begin{array}{l}\text { Aktif berpartisipasi menerangkan } \\
\text { dalam kelompok asal }\end{array}$ & 12 & 14 & 13,0 & 40,6 \\
\hline 3. & $\begin{array}{l}\text { Aktif mengikuti penjelasan materi yang } \\
\text { di terangkan tim ahli dalam diskusi. }\end{array}$ & 11 & 8 & 22,5 & 29,6 \\
\hline 4. & $\begin{array}{l}\text { Aktif berpartisipasi bertanya dalam } \\
\text { diskusi kelas }\end{array}$ & 6 & 10 & 19,5 & 24,9 \\
\hline 5. & $\begin{array}{l}\text { Aktif berpartisipasi menjawab } \\
\text { pertanyaan dalam diskusi kelas. }\end{array}$ & 13 & 11 & 12 & 37,4 \\
\hline
\end{tabular}

Cat : Total jumlah siswa adalah 32 orang.

Pada Tabel 1 terlihat bahwa aktivitas belajar biologi pada siklus I pada aktivitas mengikuti penjelasan materi yang di terangkan tim ahli dalam diskusi 
hingga mencapai $29,6 \%$, berdiskusi dalam kelompoknya 45,2\%, berpartisipasi menerangkan dalam kelompok asal 40,6,\%, dan berpartisipasi bertanya dalam diskusi $24,9 \%$, dan pada aktivitas menjawab pertanyaan dalam diskusi kelas mencapai angka $37,4 \%$

2. Data Aktivitas Belajar Negatif Siswa

Adapun hasil perhitungan observer terhadap aktivitas belajar Negatif pada siklus I adalah sebagai berikut :

\begin{tabular}{|c|c|c|c|c|c|}
\hline \multirow[t]{2}{*}{ No } & \multirow[t]{2}{*}{ Aktivitas Belajar Negatif } & \multicolumn{3}{|c|}{ Jumlah Siswa } & \multirow[t]{2}{*}{$\%$} \\
\hline & & $\begin{array}{c}\text { Pert. } \\
1\end{array}$ & $\begin{array}{c}\text { Pert. } \\
2\end{array}$ & Rataan & \\
\hline 1. & Sering keluar kelas & 18 & 15 & 16,5 & 51,5 \\
\hline 2. & Menggangu teman & 15 & 26 & 20,5 & 64,0 \\
\hline 3. & Mengerjakan pekerjaan lain & 21 & 27 & 24 & 75,0 \\
\hline 4. & Mengantuk & 26 & 24 & 25 & 78,0 \\
\hline 5. & Tidak memperhatikan & 18 & 21 & 19,5 & 60,9 \\
\hline
\end{tabular}

Pada Tabel 2 terlihat bahwa aktivitas belajar negatif pada siklus I pada aktivitas mengantuk hanya mencapai $78 \%$, mengerjakan pekerjaan lain $75,0 \%$, sering keluar kelas 51,5\%, dan mengganggu teman 64,0\% dan pada aktivitas tidak memperhatikan hingga mencapai $60,9 \%$.

\section{Refleksi Siklus I}

Dengan memperhatikan data observasi dan hasil pengamatan terhadap siswa kela XII. MIPA3 diproleh hal-hal sebagai berikut :

1. Prosentase rata-rata aktivitas yang termasuk partisipasi aktif (Positif) sebesar 35,54\% dan aktivitas negatif 51,88\%

2. Kemampuan memberikan saran, gagasan ,memperhatikan teman menerangkan ,memberikan tanggapan terhadap pertanyaan dan kemampuan memahami materi perlu ditingkatkan. Maka langkah pembelajaran pada siklus dua akan sedikit berubah yaitu sebelum masuk pada kegiatan inti siswa disuruh membaca topik yang akan dipelajari secara keseluruhan terlebih dahulu

3. Sebagian besar Siswa sangat tertarik mengikuti sistem pembelajaran kooperatif tipe Jigsaw

\section{Deskripsi Hasil Penelitian Siklus II}

Siklus dua ini dilakukan karena aktivitas belajar siswa masih rendah pada siklus pertama. Pada siklus II, Hasil penelitian yang diperoleh adalah sebagai berikut :

1. Data Aktivitas Belajar Positif Siswa

Adapun hasil perhitungan observer terhadap aktivitas belajar positif pada siklus II adalah sebagai berikut :

Tabel 3. Hasil Observasi Aktivitas Belajar positif Siswa Siklus II

\begin{tabular}{|l|l|l|l|}
\hline No & Aktivitas Belajar Positif & Jumlah Siswa & $\%$ \\
\hline
\end{tabular}




\begin{tabular}{|c|l|c|c|c|c|}
\hline & & Pert. & Pert. & Rerata & \\
\hline 1. & Aktif berdiskusi dalam kelompoknya & 23 & 24 & 23,5 & 73,4 \\
\hline 2. & $\begin{array}{l}\text { Aktif berpartisipasi menerangkan } \\
\text { dalam kelompok asal }\end{array}$ & 22 & 23 & 22,5 & 70,3 \\
\hline 3. & $\begin{array}{l}\text { Aktif mengikuti penjelasan materi } \\
\text { yang di terangkan tim ahli dalam } \\
\text { diskusi. }\end{array}$ & 18 & 21 & 19,5 & 60,9 \\
\hline 4. & $\begin{array}{l}\text { Aktif berpartisipasi bertanya dalam } \\
\text { diskusi kelas }\end{array}$ & 15 & 26 & 20,5 & 64,0 \\
\hline 5. & $\begin{array}{l}\text { Aktif berpartisipasi menjawab } \\
\text { pertanyaan dalam diskusi kelas. }\end{array}$ & 22 & 27 & 24,5 & 76,5 \\
\hline
\end{tabular}

Cat : Total jumlah siswa adalah 32 orang.

Pada masing-masing item aktivitas belajar siswa yang diamati semuanya mengalami peningkatan, baik keaktifan mengikuti berdiskusi dalam kelompok, berpartisipasi menerangkan, mengikuti penjelasan, dan bertanya serta menjawab pertanyaan dalam diskusi kelas .

2. Data Aktivitas Belajar Negatif Siswa

Adapun hasil perhitungan observer terhadap aktivitas belajar Negatif pada siklus II adalah sebagai berikut :

\begin{tabular}{|l|l|c|c|c|c|}
\hline \multicolumn{3}{|c|}{ Tabel 4. Hasil Observasi Aktivitas Belajar Negatif Siswa Siklus II } \\
\hline No & Aktivitas Belajar Negatif & \multicolumn{3}{|c|}{ Jumlah Siswa } & $\%$ \\
\cline { 3 - 5 } & & Pert.1 & Pert.2 & Rerata & \\
\hline 1. & Sering keluar kelas & 11 & 9 & 20 & 31,2 \\
\hline 2. & Menggangu teman & 6 & 19 & 12,5 & 39,0 \\
\hline 3. & Mengerjakan pekerjaan lain & 13 & 19 & 16 & 50,0 \\
\hline 4. & Mengantuk & 15 & 15 & 15 & 46,8 \\
\hline 5. & Tidak memperhatikan & 14 & 9 & 11,5 & 35,9 \\
\hline
\end{tabular}

Pada masing-masing item aktivitas belajar negatif siswa yang diamati semuanya mengalami penurunan, baik aktivitas tidak memperhatikan, mengganggu teman, dan keluar kelas serta tidak ada seorangpun siswa yang mengantuk dan mengerjakan pekerjaan lain pada saat pembelajaran berlangsung di kelas.

3. Refleksi Siklus II

Secara umum aktivitas siswa belajar kimia dengan menggunakan model pembelajaran kooperatif tipe JIGSAW pada siklus kedua mengalami peningkatan dibanding siklua pertama. Pada siklus kedua ini tampak siswa mengalami peningkatan pemahaman materi yang dipelajari. Berdasarkan pengamatan terhadap aktivitas belajar biologi, maka pada siklus kedua ditemui hal-hal sebagai berikut :

1. Sebagian siswa telah menyiapkan diri belajar biologi dengan menggunakan model pembelajaran kooperatif tipe JIGSAW dengan menguasai materimateri sebelumnya. 
2. Siswa sudah terbiasa dengan model pembelajaran kooperati tipe JIGSAW, sehingga keberlangsungan pembelajaran sesuai dengan rencana pelaksanaan pembelajaran.

3. Siswa sudah terbiasa berdiskusi baik di dalam kelompok kecil maupun di kelompok besar.

\section{A. Pembahasan}

1. Perbandingan Aktivitas Belajar Positif Siswa Siklus I dan II

Perbandingan aktivitas belajar biologi siswa menggunakan Model pembelajaran kooperatif tipe JIGSAW pada siklus I dan II, tampak bahwa terjadi peningkatan aktivitas belajar siswa dari siklus I ke siklus II, walau tidak mengalami peningkatan yang tajam terutama pada aktivitas bertanya dan menjawab pertanyaan, beberapa siswa masih terlihat enggan melakukannya walau sudah diberikan motivasi oleh guru, tapi tetap aktif memberikan kontribusi dalam melakukan aktivitas diskusi kelas. Secara keseluruhan perbandingan aktivitas belajar siswa meningkat sebanyak 23,79 $\%$ yaitu dari 33,71\% menjadi 57,50\% dapat dilihat dari gambar 1 berikut.

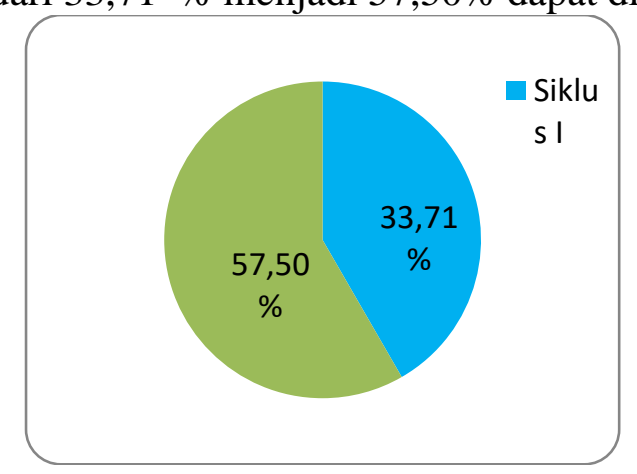

\section{Gambar 1. Perbandingan Kemajuan Aktivitas Belajar Positif Siswa Siklus I} dan II

2. Perbandingan Aktivitas Belajar Negatif Siswa Siklus I dan II

Perbandingan aktivitas belajar biologi siswa menggunakan Model pembelajaran kooperatif tipe JIGSAW pada siklus I dan II tampak bahwa terjadi penurunan aktivitas belajar negatif siswa dari siklus I ke siklus II, terjadi penurunan yang tajam terutama pada aktivitas tidak memperhatikan, sering keluar kelas, mengganggu teman, dan pada saat pembelajaran berlangsung sudah tidak ada siswa yang mengantuk dan mengerjakan pekerjaan lainnya. Secara keseluruhan perbandingan aktivitas belajar negatif siswa menurun sebanyak $4.0 \%$ yaitu dari $8,0 \%$ menjadi $4,0 \%$ dapat dilihat dari gambar 2 berikut.

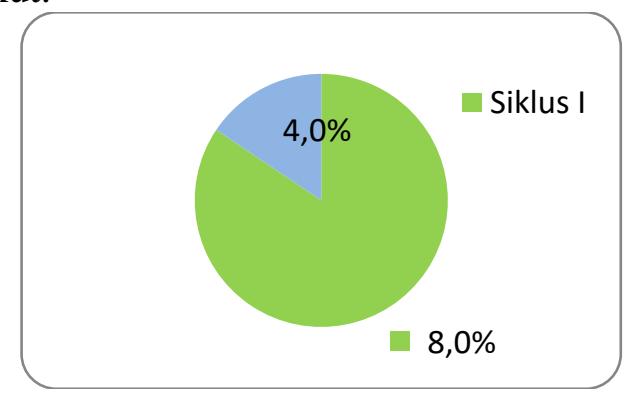

Gambar 2. Perbandingan Aktivitas Belajar Negatif Siswa Siklus I dan II 
Peningkatan aktivitas belajar positif dan penurunan aktivitas belajar Negatif dari siklus I ke siklus II memungkinkan karena proses pembelajaran kooperatif tipe JIGSAW yang telah dilaksanakan sangat menarik bagi siswa karena semua siswa dituntut serius dalam menguasai materi yang nantinya akan ia jelaskan kepada teman kelompoknya.

Jadi peningkatan rata-rata aktivitas belajar pada siklus 1 dan siklus II dapat di lihat pada histogram berikut :

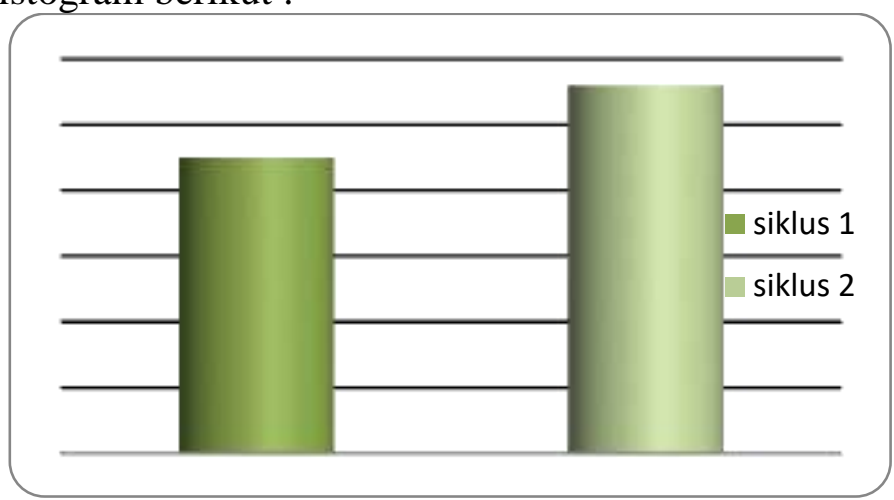

Pada histogram, tampak peningkatan rata-rata aktivitas belajar biologi dari siklus I ke siklus II, hal ini menunjukkan bahwa:

1. Siswa aktif berdiskusi dalam kelompoknya

2. Siswa aktif berpartisipasi menerangkan dalam kelompok asal

3. Siswa aktif mengikuti penjelasan materi yang di terangkan tim ahli dalam diskusi.

4. Siswa aktif berpartisipasi bertanya dalam diskusi kelas

5. Siswa aktif berpartisipasi menjawab pertanyaan dalam diskusi kelas.

6. Tanggung jawab siswa menjadi lebih meningkat

7. Siswa menjadi kreatif

\section{PENUTUP}

\section{Kesimpulan}

Berdasarkan hasil penelitian dan pembahasannya maka dari penelitian tindakan (action research) ini dapat diambil kesimpulan bahwa model pembelajaran kooperatif Jigsaw dapat meningkatkan aktivitas belajar siswa pada saat proses pembelajaran di kelas dan membuat suasana kelas saat proses pembelajaran menjadi lebih hidup. Ini terlihat pada hasil penelitian yang menunjukkan kenaikan persentasenya .

\section{Saran}

1. Guru-guru Biologi diharapkan mempergunakan metode pembelajaran yang lebih bervariasi dan fokuskan pembelajaran terhadap siswa, serta jangan melihat hasil ketercapaian berdasarkan nilai sebagai patokan utama tetapi pemahaman tiap-tiap siswa lebih diutamakan.

2. Peneliti lain dapat meneliti lebih lanjut dengan pembahasan lebih mendalam misalnya pada bidang studi lain atau jenjang pendidikan yang lain.

\section{DAFTAR PUSTAKA}


Rahadi, Ansto. 2003. Media Pembelajaran Jakarta : Dikjen Dikti Depdikbud Whittaker, James O. 1966. An introduction to psychology. Philadelphia, 1966, viii, hal. 224.

Winkel, W. S. 2005. Psikologi Pengajaran. Jakarta: Grasindo.

Arikunto, Suharsimi. 2008. Dasar-Dasar Evaluasi Pendidikan. Jakarta: Bumi Aksara.

BSNP (Badan Standar Nasional Pendidikan). 2007. Model Pembelajaran IPA Terpadu. Jakarta: Depdiknas.

Hamalik, Oemar. 2008. Proses Belajar Mengajar. Jakarta: Bumi Aksara.

Hasibuan, J.J. Moedjiono. (1988). Proses Belajar Mengajar. Jakarta: Remadja Karya.

Ibrahim, Muslim. 2000. Pembelajaran Kooperatif. Surabaya: UNESA Press.

M. Ngalim Purwanto. 1998. Psikologi Pendidikan Bandung: Remaja Rosda Karya. 